\title{
Exposure Reference Identifier
}

National Cancer Institute

\section{Source}

National Cancer Institute. Exposure Reference Identifier. NCI Thesaurus. Code C113358.

A character or string used to name, or characterize an exposure reference. 